\title{
Analisis Faktor-Faktor yang Memengaruhi Nilai Aktiva Bersih Reksadana Syariah (Periode 2016-2019)
}

\author{
Analysis of factors affecting the net assets of sharia refund (period 2016-2019)
}

\author{
Aldiansyah \\ Program Studi D4 Keuangan Syariah, Politeknik Negeri Bandung \\ Email: aldiansyah.ksy16@polban.ac.id
}

\section{Fifi Afiyanti Tripuspitorini}

Jurusan Akuntansi, Politeknik Negeri Bandung

Email: afiyanti@gmail.com

\section{Fatmi Hadiani}

Jurusan Akuntansi, Politeknik Negeri Bandung

Email: afiyanti@gmail.com

\begin{abstract}
This study aims to determine the effect of inflation, Rupiah exchange rate, SBIS yield rate, ISSI on NAV of Islamic mutual funds in Indonesia. The analytical method used is multiple linear regression using secondary data in the form of time series from January 2016 to December 2019. The independent variables analyzed in this study are inflation, rupiab exchange rates, returns on SBIS and ISSI, while the dependent variable is Asset Value. Net Sharia Mutual Funds. The results of this study indicate that inflation has no significant effect on NAV of Sharia Mutual Funds, Exchange Rate, ISSI has a significant effect on NAV of Sharia Mutual Funds, SBIS has a significant effect on $\mathrm{N} A V$ of Sharia Mutual Funds in opposite directions
\end{abstract}

Keywords: inflation, rupiah exchange rate, SBIS rate of return, ISSI, NAV of Islamic mutual funds

\section{Pendahuluan}

Investasi ialah bentuk penyimpanan dana yang dapat dijalankan oleh perusahaan kepada satu aset (aktiva) yang bertujuan mendapat keuntungan di masa depan (Martono \& Harjito, 2002). Sedangkan pasar modal adalah satu dari banyak tempat berinvestasi bagi khalayak umum. dengan demikian, penciptaan produk investasi di pasar modal dibutuhkan sebagai pilihan bagi investor untuk menyimpan dananya. Reksadana merupakan satu dari sekian bentuk investasi tersebut (Bapepam, 2012). Masyarakat pemodal dapat menggunakan Reksadana guna mengumpulkan dana lalu diinvestasikan di portofolio efek (Ikatan Akuntan Indonesia, 2007). Reksadana memberikan pilihan kepada orang-orang yang tidak memiliki banyak waktu dan dana melakukan penganekaragaman (Mankiw \& Gregory, 2006).

Dikutip (DSN-MUI, 2001) Reksadana dalam islam (Syariah) adalah reksadana yang dijalankan sesuai syariat Islam dalam bentuk akad pemilik harta (sahib al-mal) dan MI (Manajer Investasi) sebagai perantara sahib al-mal.. Kinerja Reksadana syariah diukur oleh salah satu ukuran unjuk kerja investasi yaitu Nilai Aktiva Bersih. NAB dihasilkan dari besar aktiva dikurangi dengan kewajiban yang muncul (Sudarso, 2008). 
Berikut adalah gambaran perkembangan kinerja reksadana syariah di Indonesia :

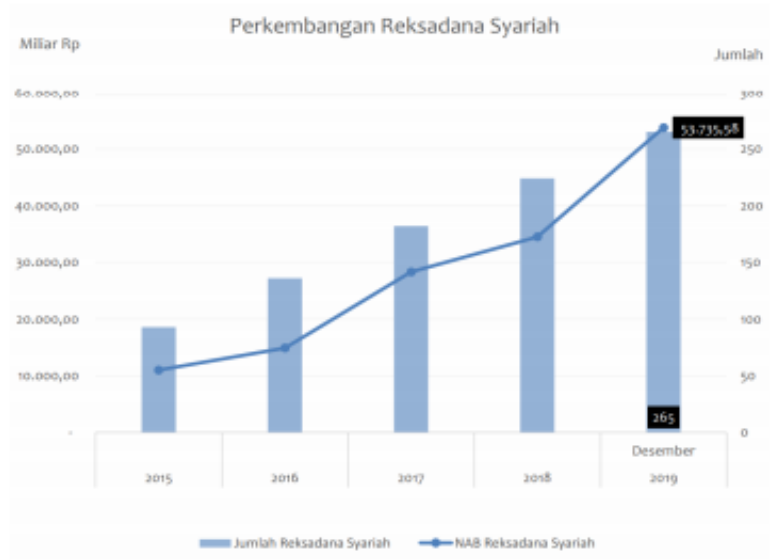

Gambar 1 Perkembangan Nilai Aktiva Bersih (NAB) Reksadana Syariah di Indonesia hingga tahun 2019

Sumber : Otoritas Jasa Keuangan

Dari grafik diatas dapat dilihat bahwa perkembangan reksadana terus mengalami peningkatan. Dapat dilihat dari kurun waktu 2015 hingga 2019 reksadana terus mengalami kenaikan yang cukup signifikan. Kinerja reksadana dipengaruhi macam-macam faktor baik internal maupun eksternal perusahaan. seorang investor yang hendak melakukan suatu investasi harus mempertimbangkan analisis kondisi makroekonomi, jenis industri, serta analisis fundamental perusahaan.(Sentanoe Kertonegoro, 1995).

Berikut merupakan grafik perkembangan NAB Reksadana Syariah, Inflasi, Kurs, ISSI dan tingkat imbal hasil SBIS:

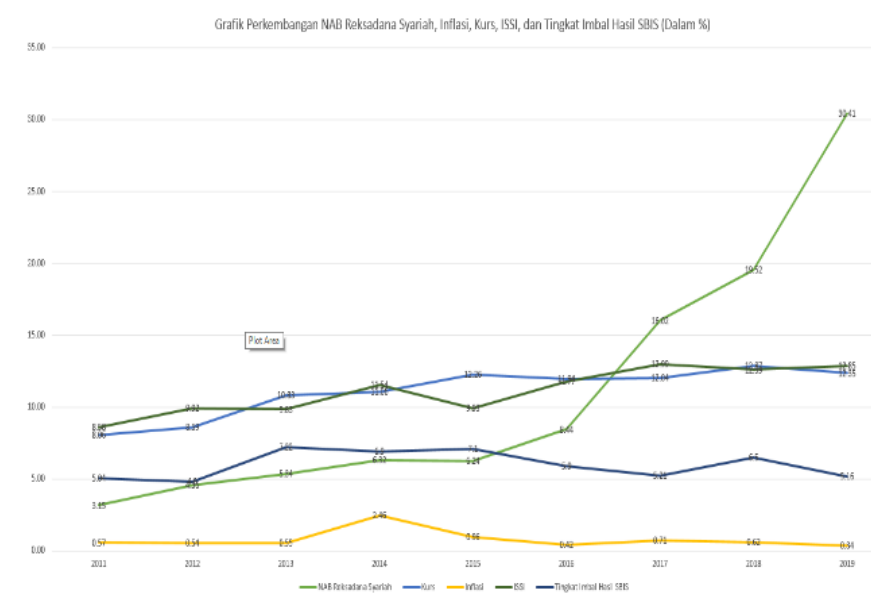

Gambar 2 Grafik Pergerakan NAB Reksadana Syariah, Inflasi, Kurs, SBIS, ISSI dalam Persentase $(\%)$

Sumber : Data Diolah

Grafik diatas menunjukkan perubahan NAB Reksadana Syariah, Inflasi, Kurs, serta Tingkat Imbal Hasil SBIS periode 2011-2019. Dari tahun 2016-2019, peningkatan yang sangat pesat terjadi pada NAB reksadana syariah.

Inflasi memicu meningkatnya harga barang maupun jasa perusahaan mengalami penurunan laba, selanjutnya mempengaruhi bagi hasil yang akan diberikan kepada investor, akibatnya investasi 
akan kurang menarik karena tidak dapat memberikan hasil yang diinginkan. Selanjutnya perusahaan mengalami penurunan harga saham, diikuti dengan NAB reksadana syariah mengalami penurunan pula (Putratama, 2007). Inflasi mencerminkan stabilitas ekonomi, secara teori inflasi bisa melemahkan semangat masyarakat untuk menabung (Marginal Propensity to Save) turun, kecenderungan berbelanja meningkat (Marginal Propensity to Consume) naik dan akan mengarah terhadap investasi non-produktif (Linda Sri \& Fifi Afiyanti, 2013).

Exchange Rate (nilai tukar uang) atau kurs mata uang adalah catatan harga pasar dari mata uang asing (foreign currency) atau resiprokalnya, yaitu harga mata uang domestik dalam mata uang asing (Rezky et al., 2020). negara dengan harga mata uang negara lain. Dengan demikian dapat dikatakan bahwa nilai tukar merupakan salah satu alat pengukur kondisi makroekonomi suatu negara. Hal tersebut dapat menunjukkan kemampuan relatif dari perekonomian suatu negara terhadap negara lainnya (Afiyanti \& Setiawan, 2020). kurs adalah variabel makroekonomi yang turut memengaruhi validitas harga saham, nilai tukar rupiah yang tidak stabil dapat mengubah faktor produksi perusahaan. Nilai tukar yang turun akan meningkatkan biaya produksi serta hutang perusahaan, sehingga tingkat return yang dibagikan tidak lagi menarik investor untuk berinventasi yang akhirnya berdampak pada menurunnya nilai aktiva bersih perusahaan (Nandari Ayu, 2016).

Faktor selanjutnya adalah SBIS, Sertifikat Bank Indonesia Syariah dalam jangka pendek berpengaruh negatif terhadap NAB reksadana syariah. Jika suku bunga SBIS dinaikkan maka kebanyakan investor akan beralih ke SBIS dan menjual unit penyertaannya (Islam, 2018).

ISSI adalah indeks saham yang menggambarkan semua saham syariah yang ada di Bursa Efek Indonesia. Konstituennya merupakan keseluruhan saham syariah yang ada di BEI (Bursa Efek Indonesia) serta terdaftar di DES (Daftar Efek Syariah) yang dibuat oleh Otoritas Jasa Keuangan (IDX, 2019). Menurut (Sherlyana, 2016) dalam jangka panjang ISSI memberikan pengaruh positif terhadap kinerja reksadana syariah, selanjutnya jika ISSI terus membaik dalam jangka panjang maka NAB reksadana syariah akan memperoleh peningkatan.

Berdasarkan gap penelitian dan fenomena diatas, penulis tertarik untuk melakukan penelitian dengan judul "Analisis Faktor-Faktor yang Mempengaruhi Nilai Aktiva Bersih Reksadana Syariah"

\section{Kajian Pustaka}

\section{Pengertian Reksadana Syariah}

Reksadana syariah adalah instrumen investasi yang dapat dipilih masyarakat yang ingin mendapatkan keuntungan dengan syariat islam. Reksadana syariah memiliki tanggung sosial terhadap nilai-nilai keagamaan, terhadap lingkungan dan tidak semata-mata mencari keuntungan tapi tidak menyisihkan kepentingan orang-orang yang berinvestasi (Susanto, 2008).

\section{NAB (Nilai Aktiva Bersih) Reksadana Syariah}

NAB (Net Asset Value) merupakan sejumlah asset yang dikurangi kewajiban yang muncul, dengan kata lain NAB adalah kas dan semua investasi yang ada lalu dikurangi cost hutang dari kegiatan operasional yang harus dibayarkan. (Inggi, 2000)

Nilai aktiva bersih dapat diformulasikan sebagai berikut : (Rodoni A 2009) 


\author{
$\mathrm{NAVt}=(\mathrm{NVAt}-\mathrm{LIABt})$ \\ Keterangan: \\ NAVt= Nilai aktiva Bersih Periode $t$ \\ NVAt $=$ total nilai pasar Aktiva periode $\mathrm{t}$ \\ LIABt $=$ total kewajiban reksadana periode $\mathrm{t}$

\section{Gambar 3 Rumus NAB \\ Sumber: Data Diolah}

\title{
Hubungan Inflasi terhadap NAB Reksadana Syariah
}

Inflasi merupakan suatu kondisi dimana jumlah barang yang beredar lebih sedikit dari jumlah permintaan sehingga akan mengakibatkan kenaikan harga yang meluas dan terus menerus dalam sistem perekonomian secara keseluruhan. Inflasi berakibat sangat buruk bagi perekonomian karena (i) menimbulkan gangguan terhadap fungsi uang, terutama terhadap fungsi tabungan (nilai simpan), (ii) melemahkan semangat menabung dan sikap terhadap menabung dari masyarakat (turunnya Marginal Propensity to Save), (iii) meningkatkan kecenderungan untuk berbelanja terutama untuk non-primer dan barang-barang mewah naiknya (Marginal Propensity to Consume), dan (iv) mengarahkan investasi pada hal-hal yang nonproduktif yaitu penumpukan kekayaan (boarding) seperti tanah, bangunan, logam mulia, mata uang asing dengan mengorbankan investasi ke arah produktif seperti pertanian, industrial, perdagangan, transportasi dan lainnya (Karim \& Adiwarman, 2001).

Berdasarkan uraian diatas maka penulis mendapatkan hipotesis

$\mathrm{H} 1$ : Inflasi $\left(\mathrm{X}_{1}\right)$ secara parsial berpengaruh signifikan terhadap Nilai Aktiva Bersih Reksadana Syariah (Y)

\section{Hubungan Kurs terhadap NAB Reksadana Syariah}

Fluktuasi nilai rupiah terhadap mata uang asing yang stabil akan sangat mempengaruhi iklim investasi dalam negeri, khususnya pasar modal. Terjadinya apresiasi kurs rupiah terhadap dollar misalnya akan memberikan dampak terhadap perkembangan persaingan produk Indonesia di luar negeri, terutama dalam hal persaingan harga. Apabila ini terjadi, secara tidak langsung akan memberikan pengaruh terhadap neraca perdagangan karena meningkatnya nilai ekspor dibandingkan nilai impor, sebaliknya akan berpengaruh pula kepada neraca pembayaran Indonesia. Memburuknya neraca pembayaran negara akan berpengaruh terhadap cadangan devisa, berkurangnya cadangan devisa akan mempengaruhi kepercayaan investor terhadap perekonomian Indonesia, yang selanjutnya menimbulkan dampak negatif terhadap perdagangan saham di pasar modal. Keadaan ini, bagi investor asing akan cenderung melakukan penarikan modal sehingga terjadi capital inflow. Hal ini juga menyebabkan menurunnya NAB reksadana karena pengelolaan dana investasi reksadana yang sebagian dialokasikan pada saham mengakibatkan kemungkinan investor yang menginvestasikan dananya pada reksadana saham akan melakukan penarikan modal sehingga NAB reksadana pun mengalami penurunan.

Berdasarkan uraian diatas maka penulis mendapatkan hipotesis

$\mathrm{H} 2$ : Nilai Tukar Rupiah $\left(\mathrm{X}_{2}\right)$ secara parsial berpengaruh signifikan terhadap Nilai Aktiva Bersih Reksadana Syariah (Y)

\section{Hubungan SBIS terhadap NAB Reksadana Syariah}

SBIS adalah indikator untuk melihat aktivitas pasar uang syariah. NAB dengan SBIS menunjukkan hubungan yang negatif, Jika SBIS menurun maka NAB meningkat. Dengan turunnya SBIS akan mempengaruhi iklim investasi di pasar modal dan pasar uang syariah. 
Turunnya tingkat SBIS pula menyebabkan turunnya tingkat equivalen rate nisbah simpanan dan deposito mudharabah, maka investasi akan berpindah ke instrument yang memberikan tingkat keuntungan/Bagi hasil yang lebih tinggi di pasar modal seperti Reksadana Syariah (Agustina, 2015).

Berdasarkan uraian diatas maka penulis mendapatkan hipotesis

H3 : Sertifikat Bank Indonesia Syariah $\left(\mathrm{X}_{3}\right)$ secara parsial berpengaruh signifikan terhadap Nilai Aktiva Bersih Reksadana Syariah (Y)

\section{Hubungan ISSI terhadap NAB Reksadana Syariah}

Indeks Saham Syariah Indonesia (ISSI) merupakan indeks saham yang mencerminkan keseluruhan saham syariah yang tercatat di Bursa Efek Indonesia (BEI). Peningkatan ISSI mencerminkan kinerja perusahaan yang meningkat sehingga berpotensi untuk memperoleh pendapatan yang lebih besar. Pendapatan perusahaan yang meningkat akan menyebabkan kenaikan return bagi hasil Reksa Dana Syariah. Oleh karena itu masyarakat akan menginvestasikan dananya melalui Reksa Dana Syariah dengan harapan memperoleh return yang lebih besar. ISSI juga memberikan pengaruh positif terhadap kinerja reksadana syariah menurut penelitian Riska Yanty (2017). Kinerja saham yang terus membaik akan menyebabkan banyak orang yang tertarik membeli saham, maka harga saham cenderung akan mengalami kenaikan dan nilai aktiva bersih reksadana syariah akan mengalami peningkatan.

Berdasarkan uraian diatas maka penulis mendapatkan hipotesis

$\mathrm{H} 4$ : Indeks Saham Syariah Indonesia $\left(\mathrm{X}_{4}\right)$ secara parsial berpengaruh signifikan terhadap Nilai Aktiva Bersih Reksadana Syariah (Y)

\section{Hubungan Inflasi, Kurs, SBIS, ISSI Terhadap NAB Reksadana Syariah}

Variabel Makroekonomi secara langsung maupun tidak langsung mempengaruhi fluktuasi Nilai Aktiva Bersih Reksadana syariah, hal ini terjadi karena keterkaitan antara kondisi makroekonomi terhadap keadaan pasar modal syariah khususnya reksadana syariah, dengan kata lain jika kinerja variabel-variabel makroekonomi yang dalam penelitian ini yaitu Inflasi, Kurs, SBIS, dan ISSI atau keadaan ekonomi secara keseluruhan membaik maka NAB Reksadana syariah akan meningkat nilainya, sedangkan jika keadaan ekonomi memburuk maka NAB Reksadana Syariah akan menurun nilainya

Berdasarkan uraian diatas maka penulis mendapatkan hipotesis

H5 : Inflasi $\left(\mathrm{X}_{1}\right)$, Nilai Tukar Rupiah $\left(\mathrm{X}_{2}\right)$, Sertifikat Bank Indonesia Syariah $\left(\mathrm{X}_{3}\right)$, Indeks Saham Syariah Indonesia $\left(\mathrm{X}_{4}\right)$ berpengaruh secara simultan terhadap Nilai Aktiva Bersih Reksadana Syariah (Y).

\section{Metode Penelitian}

Ruang lingkup penelitian ini dengan meneliti empat Independent variable seperti Inflasi, Nilai Tukar Rupiah, SBIS, ISSI bila diteliti dengan Dependent variable dalam penelitian ini yaitu NAB Reksadana Syariah periode Januari 2016 - Desember 2019. Data merupakan data bulanan, dan jenis datanya adalah data Time Series. Sumber data sekunder yang didapat diperoleh dari berbagai sumber seperti website Bank Indonesia, BPS, dan lain sebagainya, dengan metode pengumpulan data studi pustaka yaitu penelusuran literatur, buku, artikel maupun jurnal. Metode analisis di penelitian ini ialah regresi linier berganda dengan data diuji dengan uji asumsi klasik.

\section{Hasil dan Pembahasan}

Bagian ini merupakan bagian utama artikel hasil penelitian dan biasanya merupakan bagian terpanjang dari suatu artikel. Hasil penelitian yang disajikan dalam bagian ini adalah hasil "bersih". 
Hasil "bersih" sebagai dasar proses analisis data seperti hasil perhitungan statistik dan untuk proses pengujian hipotesis. Hasil bersih meliputi Tabel dan grafik hasil perhitungan statistik, persamaan regresi yang dihasilkan dan gambar Model Hasil Analisis sebagai dasar untuk pembahasan.

\section{Uji Asumsi Klasik}

\section{Uji Normalitas}

Uji Normalitas ditujukan untuk mengetahui apakah variabel bebas atau terikat maupun keduanya tersebar secara normal. Model regresi yang baik harus tersebar normal ataupun mendekati normal, hal ini dapat dideteksi dengan melihat penyebaran data melalui sebuah grafik, jika data tersebar sepanjang garis diagonal maka data diasumsikan memenuhi normalitas.

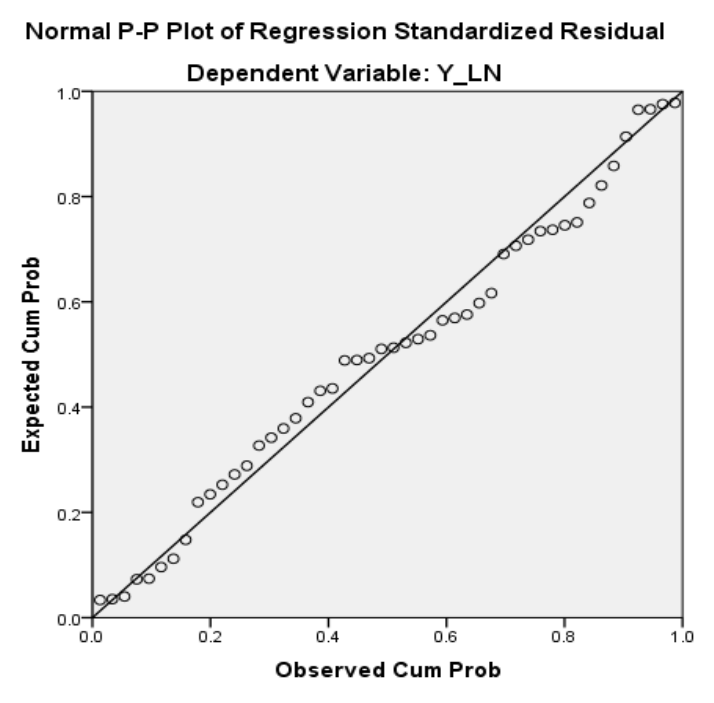

Gambar 4 Uji Normalitas Sumber : SPSS 22 for Windows

Pada gambar diatas terlihat titik sebaran data tersebar pada garis diagonal, maka data dapat diasumsikan memenuhi uji normalitas.

\section{Uji Heteroskedastisitas}

Uji ini ditujukan untuk menguji apakah dalam model regresi terdapat ketidaksamaan variasi residual dari satu pengamatan ke yang lainnya, model regresi seharusnya tidak terdapat heteroskedastisitas. 


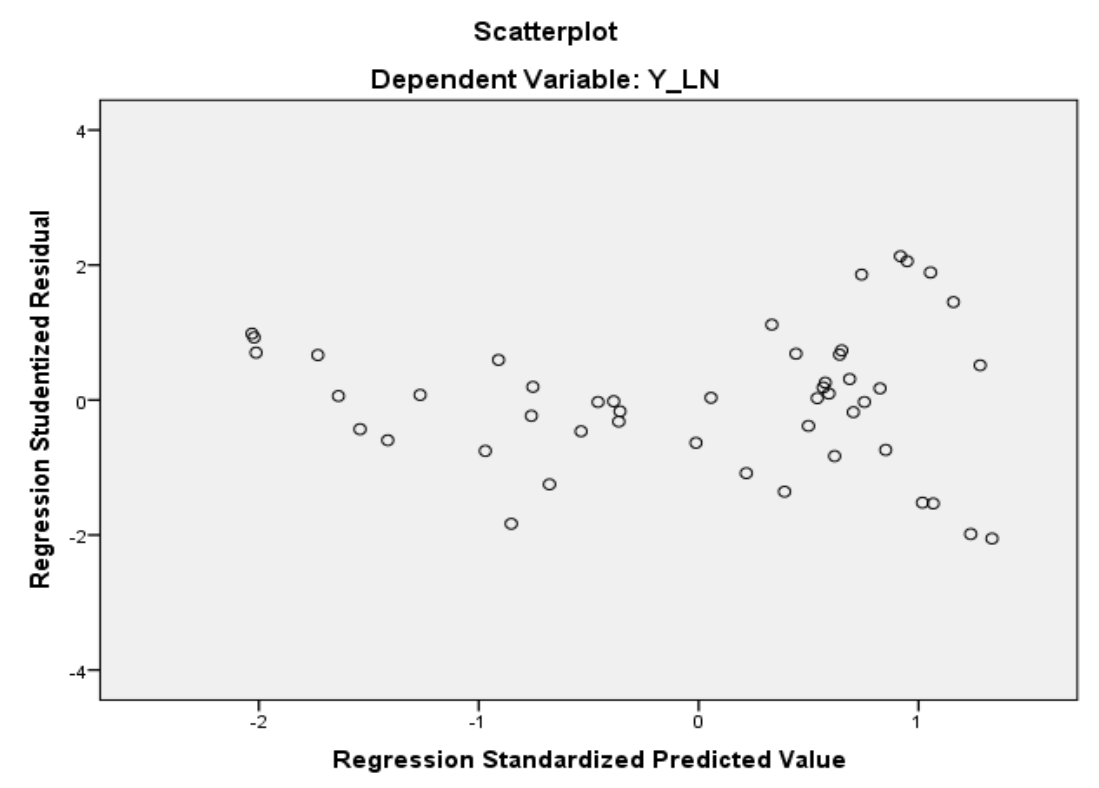

Gambar 5 Uji Heteroskedastisitas

Sumber : SPSS 22 For Windows

Berdasarkan Gambar diatas, ini tidak terdapat heteroskedastisitas, tidak pola tertentu yang terbentuk, titik-titik menyebar diantara titik nol.

\section{Uji Autokorelasi}

Uji autokorelasi ditujukan untuk menguji apakah terdapat hubungan antara kesalahan pengganggu pada suatu periode dengan periode setelahnya atau sebelumnya. korelasi dapat terjadi jika ada masalah autokorelasi pada data, model regresi sebaiknya tidak mengandung masalah autokorelasi. uji untuk menguji masalah autokorelasi adalah uji Durbin Watson, dengan kriteria keputusan jika nilai DW ada diantara -2 dan 2 maka tidak terjadi autokorelasi, jika kurang dari -2 maka terjadi autokorelasi positif, sebaliknya, jika lebih dari 2 maka terjadi autokorelasi negatif.

\section{Tabel 1 Uji DW}

Model Summary

\begin{tabular}{|l|r|r|r|r|r|}
\hline Model & \multicolumn{1}{|c|}{$\mathrm{R}$} & R Square & \multicolumn{1}{c|}{$\begin{array}{c}\text { Adjusted R } \\
\text { Square }\end{array}$} & $\begin{array}{c}\text { Std. Error of the } \\
\text { Estimate }\end{array}$ & Durbin-Watson \\
\hline 1 & $.946^{\mathrm{a}}$ & .895 & .886 & .18878 & .811 \\
\hline
\end{tabular}

a. Predictors: (Constant), issi, inflasi, LN_Kurs, sbis

b. Dependent Variable: Y_LN

Sumber : SPSS 22 For Windows

Berdasarkan Tabel diatas angka durbin watson yang diperoleh sebesar 0,811. Nilai ini menunjukkan bahwa nilai DW berada diantara -2 sampai 2, artinya tidak terjadi masalah autokorelasi. 


\section{Uji Multikolinearitas}

Uji Multikolinearitas ditujukan guna melihat pengaruh antar variabel bebas, multikolinearitas tidak terjadi jika koefisien korelasi (VIF) antar variabel $\leq 10$ dan nilai Tolerance $\geq 0,10$.

Tabel 2 Uji Multikolinearitas

\begin{tabular}{|c|c|c|c|c|c|c|}
\hline \multicolumn{7}{|c|}{ Coefficientsa } \\
\hline \multirow{2}{*}{\multicolumn{2}{|c|}{ Model }} & \multicolumn{2}{|c|}{ Unstandardized Coefficients } & \multirow{2}{*}{$\begin{array}{c}\text { Standardized } \\
\text { Coefficients }\end{array}$} & \multicolumn{2}{|c|}{ Collinearity Statistics } \\
\hline & & B & Std. Error & & Tolerance & VIF \\
\hline \multirow[t]{5}{*}{1} & (Constant) & -87.571 & 7.384 & & & \\
\hline & inflasi & -.035 & .096 & -.018 & .994 & 1.006 \\
\hline & LN_Kurs & 9.951 & .799 & .666 & .851 & 1.175 \\
\hline & sbis & -.237 & .053 & -.249 & .766 & 1.306 \\
\hline & iseji & 024 & 003 & 484 & 769 & 1301 \\
\hline
\end{tabular}

$$
\text { Sumber : SPSS } 22 \text { For Windows }
$$

Nilai VIF Inflasi sebesar 1,006, VIF untuk Kurs sebesar 1,175, VIF untuk SBIS sebesar 1,306, dan VIF untuk ISSI sebesar 1,301. Melihat hasil VIF pada semua variabel penelitian berada dibawah nilai $10(\leq 10)$ dan Nilai Tolerance semua variabel lebih dari atau sama dengan $0,10(\geq$ 0,10), kesimpulannya tidak terdapat gejala multikolinearitas.

\section{Analisis Regresi Linier Berganda}

Penelitian ini menganalisis pengaruh variabel Kurs, Inflasi, ISSI, SBIS terhadap NAB Reksadana Syariah Periode Januari 2016 sampai dengan Desember 2019.

\section{Uji T}

Tabel 3 Uji T

\begin{tabular}{|c|c|c|c|c|c|c|c|c|}
\hline \multirow[b]{2}{*}{ Model } & & \multicolumn{2}{|c|}{$\begin{array}{l}\text { Unstandardized } \\
\text { Coefficients }\end{array}$} & \multirow{2}{*}{$\begin{array}{c}\text { Standardized } \\
\text { Coefficients } \\
\text { Beta }\end{array}$} & \multirow[b]{2}{*}{$t$} & \multirow[b]{2}{*}{ Sig. } & \multicolumn{2}{|c|}{ Collinearity Statistics } \\
\hline & & B & Std. Error & & & & Tolerance & VIF \\
\hline \multirow[t]{5}{*}{1} & (Constant) & -87.571 & 7.384 & & -11.860 & .000 & & \\
\hline & inflasi & -.035 & .096 & -.018 & -.368 & .715 & .994 & 1.006 \\
\hline & LN_Kurs & 9.951 & .799 & .666 & 12.449 & .000 & .851 & 1.175 \\
\hline & sbis & -.237 & .053 & -.249 & -4.425 & .000 & .766 & 1.306 \\
\hline & issi & .024 & .003 & .484 & 8.612 & .000 & .769 & 1.301 \\
\hline
\end{tabular}

a. Dependent Variable: Y_LN

Sumber: SPSS 22 For Windows

Berdasarkan tabel diatas, dapat dijelaskan dijelaskan hasil perhitungan uji t pada masingmasing variabel; 
H1 : Inflasi (X1) secara parsial berpengaruh signifikan terhadap Nilai Aktiva Bersih Reksadana Syariah (Y)

Berdasarkan tabel diatas diperoleh hasil dari variabel inflasi (X1) terhadap NAB Reksadana Syariah dimana nilai $\mathrm{T} \neg$ hitung $=-0,368$ yang artinya Thitung $<$ ttabel $(-0,368<2,017)$ nilai tersebut lebih kecil dari Ttabel Dengan signifikansi 0,715 > 0,05 yang menunjukkan tingkat signifikansi lebih besar daripada tingkat kesalahan. Berdasarkan kriteria keputusan $\mathrm{H} 0$ ditolak jika (Sig $<0,05)$ dan $\mathrm{H} 0$ diterima jika (Sig > 0,05). Dari hasil pengujian maka dapat disimpulkan jika $\mathrm{H} 0$ diterima dan H1 ditolak karena (Sig 0,715 > 0,05) yang artinya secara parsial variabel Inflasi tidak berpengaruh signifikan terhadap NAB Reksadana Syariah.

H2 : Nilai Tukar Rupiah (X2) secara parsial berpengaruh signifikan terhadap Nilai Aktiva Bersih Reksadana Syariah (Y)

Berdasarkan tabel diatas diperoleh hasil dari variabel Kurs (X2) terhadap NAB Reksadana Syariah dimana nilai $\mathrm{T} \neg$ hitung $=12,449$ yang artinya Thitung $>$ ttabel $(12,449>2,017)$ nilai tersebut lebih besar dari Ttabel Dengan signifikansi $0,000<0,05$ yang menunjukkan tingkat signifikansi lebih kecil daripada tingkat kesalahan. Berdasarkan kriteria keputusan H0 ditolak jika $($ Sig $<0,05)$ dan H0 diterima jika (Sig $>0,05)$. Dari hasil pengujian maka dapat disimpulkan jika H0 ditolak dan H3 diterima karena (Sig 0,000 < 0,05) yang artinya secara parsial variabel Kurs berpengaruh signifikan terhadap NAB Reksadana Syariah.

H3 : Sertifikat Bank Indonesia Syariah (X3) secara parsial berpengaruh signifikan terhadap Nilai Aktiva Bersih Reksadana Syariah (Y)

Berdasarkan tabel diatas diperoleh hasil dari variabel SBIS (X3) terhadap NAB Reksadana Syariah dimana nilai Thitung $=-4,425$ yang artinya Thitung $<$ ttabel $(-4,425<2,017)$ nilai tersebut lebih kecil dari Ttabel Dengan signifikansi $0,000<0,05$ yang menunjukkan tingkat signifikansi lebih kecil daripada tingkat kesalahan. Berdasarkan kriteria keputusan H0 ditolak jika (Sig < 0,05) dan $\mathrm{H0}$ diterima jika (Sig $>0,05)$. Dari hasil pengujian maka dapat disimpulkan jika H0 ditolak dan H3 diterima karena (Sig 0,000<0,05) yang artinya secara parsial variabel Nilai SBIS berpengaruh signifikan terhadap NAB Reksadana Syariah.

H4 : Indeks Saham Syariah Indonesia (X4) secara parsial berpengaruh signifikan terhadap Nilai Aktiva Bersih Reksadana Syariah (Y)

Berdasarkan tabel diatas diperoleh hasil dari variabel ISSI (X4) terhadap NAB Reksadana Syariah dimana nilai $\mathrm{T} \neg$ hitung $=8,612$ yang artinya Thitung $>$ ttabel $(12,449>2,017)$ nilai tersebut lebih besar dari Ttabel Dengan signifikansi $0,000<0,05$ yang menunjukkan tingkat signifikansi lebih kecil daripada tingkat kesalahan. Berdasarkan kriteria keputusan $\mathrm{H0}$ ditolak jika $(\mathrm{Sig}<0,05)$ dan H0 diterima jika (Sig $>0,05)$. Dari hasil pengujian maka dapat disimpulkan jika H0 ditolak dan H4 diterima karena (Sig 0,000<0,05) yang artinya secara parsial variabel Indeks saham Syariah Indonesia berpengaruh signifikan terhadap NAB Reksadana Syariah. 
Uji F

Tabel 4 Uji F

ANOVA

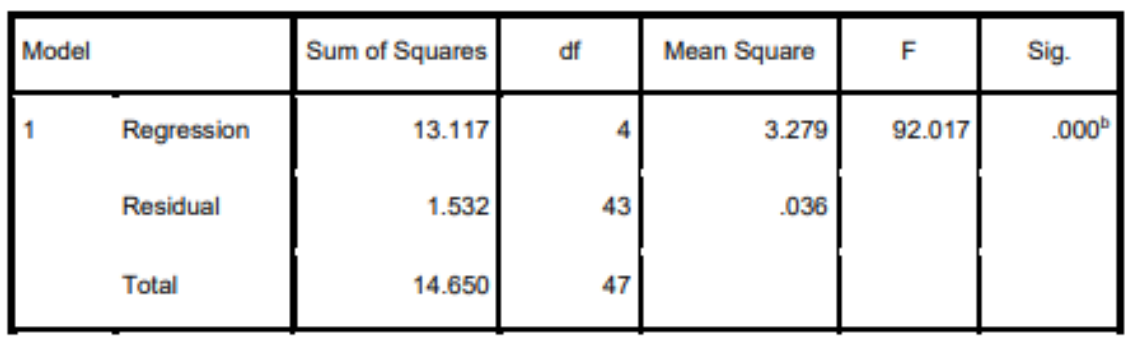

a. Dependent Variable: Y_LN

b. Predictors: (Constant), issi, inflasi, LN_Kurs, sbis

Dasar pengambilan keputusan Uji $F$ (Simultan) berdasarkan kriteria. Jika Nilai $F_{\text {hitung }}>F_{\text {tabel }}$ maka variabel independen secara simultan berpengaruh terhadap variabel dependen dan sebaliknya. Jika nilai Sig $<0,05$ maka variabel independen secara simultan berpengaruh signifikan terhadap variabel dependen. Berdasarkan tabel 4.5 bahwa nilai $F_{\text {hitung }}$ pada model penelitian adalah 92,017 dengan taraf signifikansi 0,000. Nilai sig $<$ dari 0,05 menunjikkan bahwa variabel bebas secara serentak mempunyai pengaruh yang signifikan $(0,000<0,05)$ terhadap NAB Reksadana Syariah pada signifikansi 5\%. Hasil statistic $\mathrm{F}_{\text {tabel }}$ pada tingkatan signifikansi 5\% dengan nilai Df1 adalah 4 dan nilai Df2 adalah adalah 43 diperoleh $F_{\text {tabel }}$ sebesar 2,59. Dari hasil perbandingan maka dapat disimpulkan bahwa secara simultan variabel bebas berpengaruh signifikan terhadap NAB Reksadana Syariah.

\section{Adjusted $\mathbf{R}^{2}$}

Tabel 5 Adjusted $\mathrm{R}^{2}$

Model Summary

\begin{tabular}{|l|r|r|r|r|r|}
\hline Model & $\mathrm{R}$ & $\mathrm{R}$ Square & \multicolumn{1}{c|}{$\begin{array}{c}\text { Adjusted R } \\
\text { Square }\end{array}$} & $\begin{array}{c}\text { Std. Error of the } \\
\text { Estimate }\end{array}$ & Durbin-Watson \\
\hline 1 & $.946^{\mathrm{a}}$ & .895 & .886 & .18878 & .811 \\
\hline
\end{tabular}

a. Predictors: (Constant), issi, inflasi, LN_Kurs, sbis

b. Dependent Variable: Y_LN

Dari tabel koefisien determinasi diatas, dapat diketahui bahwa nilai koefisien Adjusted R2 sebesar 0,886 atau 88,6\% Variabel Inflasi, Kurs, SBIS dan ISSI dapat menjelaskan variabel NAB Reksadana Syariah, sedangkan sisanya sebesar 11,4\% dijelaskan oleh variabel lain yang tidak diteliti pada penelitian ini.

\section{Penutup}

Berdasarkan hasil penelitian ini, Secara parsial, Inflasi tidak berpengaruh signifikan terhadap NAB Reksadana Syariah periode 2016-2019, secara parsial, Kurs berpengaruh signifikan terhadap NAB Reksadana Syariah periode 2016-2019, secara parsial, SBIS berpengaruh signifikan terhadap NAB Reksadana Syariah periode 2016-2019 secara berlawanan arah, secara parsial ISSI 
berpengaruh signifikan terhadap NAB reksadana syariah periode 2016-2019, adapun secara simultan keempat variabel mempunyai pengaruh yang signifikan terhadap NAB Reksadana Syariah periode 2016 hingga 2019.

Penlitian ini hanya terbatas pada periode penelitian yaitu 2016-2019, serta hanya terbatas pada empat variabel makroekonomi dan diperlukan pengembangan variabel makroekonomi yang lain seperti jumlah uang beredar, IHSG, tingkat pendapatan nasional dan lain sebagainya atau meneliti selain dengan metode analisis regresi linier berganda sehingga tercipta penelitian yang berkelanjutan. Adapun penelitian ini semoga dapat dijadikan bahan pertimbangan bagi investor maupun perusahaan guna menjadi landasan pengambilan keputusan khususnya kegiatan yang terkait dengan reksadana syariah, bagi akademisi diharapkan dapat menjadi literatur bagi penelitian yang akan dilakukan di masa depan.

\section{Daftar Pustaka}

Agustina, R. (2015). Pengaruh Sertifikat Bank Indonesia Syariah (SBIS), Inflasi, dan Jakarta Islamic Index (JII), terhadap Nilai Aktiva Berisih (NSB) Danareksa Syariah Berimbang periode Oktober 2010 sampai dengan Maret 2013. SKRIPSI Fakultas Ekonomi Dan Bisnis Islam Universitas Islam Negeri Raden Fatah Palembang.

Bapepam, L.-K. (2012). Peraturan Ketua Badan Pengawas Pasar Modal Dan Lembaga Kenangan. Kementrian Keuangan Republik Indonesia.

DSN-MUI. (2001). Fatwa Dewan Syari'ah Nasional untuk Reksa Dana Syariah.

Fifi, Afiyanti, T., \& Setiawan. (2020). Pengaruh Faktor Makroekonomi Terhadap Pertumbuhan Dana Pihak Ketiga Bank Umum Syariah Di Indonesia. Jurnal Riset Akuntansi Dan Kenangan, 8(1). https://doi.org/10.24912/jmieb.v4i1.7299

IDX. (2019). ISSI. https://www.idx.co.id/idx-syariah/indeks-saham-syariah/

Indonesia, Ikatan, A. (2007). Standar Akuntansi Keuangan. Salemba Empat.

Inggi, A. (2000). Investasi Syariah di Pasar Modal: Menggagas Konsep dan Praktek Manajemen Portofolio Syariah. Gramedia Pustaka Utama.

Islam, M. S. (2018). Pengaruh Jumlah Uang Beredar, Nilai Tukar Rupiah, Inflasi, dan Sertifikat Bank Indonesia Syariah (SBIS) terhadap Nilai Aktiva Bersih Reksadana syariah. Studi Kasus : PNM Ekuitas Syariah. Skripsi Fakultas Ekonomi Dan Bisnis UIN Syarif Hidayatullah Jakarta, $M m, 61$.

Karim, A., \& Adiwarman. (2001). Ekonomi Islam Suatu Kajian Kontemporer. Gema Insani.

Linda Sri, A., \& Fifi Afiyanti, T. (2013). ANALISIS PENGARUH DANA PIHAK KETIGA, NON PERFORMING FINANCE MURABAHAH, DAN INFLASI TERHADAP PEMBIAYAAN MURABAHAH PADA BANK UMUM SYARIAH DI INDONESIA. Jurnal Maps (Manajemen Perbankan Syariab), 52-64.

Mankiw, N., \& Gregory. (2006). Makro Ekonomi (F. Liza \& I. Nurmawan (eds.)). Erlangga.

Martono, \& Harjito, D. A. (2002). Manajemen Keuangan. Ekonisia.

Nandari, Ayu, Ratna, Dwi, Utami, H. (2016). PENGARUH INFLASI, KURS DAN BI RATE TERHADAP NILAI AKTIVA BERSIH (NAB) REKSADANA SYARLAH DI INDONESLA (PERIODE 2010-2016). INSTITUT AGAMA ISLAM NEGERI TULUNGAGUNG.

Putratama, H. (2007). Analisis Faktor-faktor yang Mempengarubi Perkembangan Nilai Aktiva Bersib Reksadana Syariah di Indonesia. Institut Pertanian Bogor.

Rezky, A., Radia, P., \& Setiawan. (2020). FAKTOR - FAKTOR YANG MEMPENGARUHI PEMBIAYAAN SEKTOR KONSTRUKSI PADA PERBANKAN SYARIAH DI INDONESIA. Jurnal Ekonomi Dan Perbankan, 5(1), 15-26.

Rodoni, A. (2009). Investasi Syariah. Lembaga Penelitian UIN Jakarta. 
Sentanoe Kertonegoro. (1995). Analisa dan Manajemen Investasi. Widya Press.

Sudarso, H. (2008). Bank dan Lembaga Keuangan Syariah (3rd ed.). Ekonisia.

Susanto, B. (2008). Pasar Modal Syariah (Tinjauan Hukum). UII Press Yogyakarta.

Tripuspitorini, F.A. \& Setiawan, S. (2020). Pengaruh Faktor Makroekonomi Terhadap Pertumbuhan Dana Pihak Ketiga Pada Bank Umum Syariah di Indonesia. Jurnal Riset Akuntansi dan Keuangan, 8 (1), 121-132

Yanty, R. (2017). ANALISIS PENGARUH JAKARTA ISLAMIC INDEX, INDEKS SAHAM SYARLAH INDONESIA , DAN JUMLAH REKSADANA TERHADAP.

Yuda, S. (2016). Analisis Faktor-Faktor Yang Mempengarubi Nilai Aktiva Bersib Reksadana Syariah Indonesia. 